\title{
Privatization of Water and Sanitation Services in Kenya: Challenges and Prospects
}

\author{
Kenneth O. Nyangena*
}

\begin{abstract}
Public sector utilities in developing countries have often not been efficient in providing access to reliable water and sanitation services. Worldwide, over 1 billion people lack access to improved water sources and 2.6 billion lack access to appropriate sanitation. ${ }^{1}$ Countries across the world are increasingly looking to the private sector for help in providing needed water services. Towards this end, privatization of water and sanitation services is viewed to be a cost effective method of service delivery that also enhances quality and performance. This paper seeks to highlight general knowledge, attitudes and practices of privatization of the service providers in the water and sanitation sector. It also underlines current challenges in the management of privatization of water and sanitation services in Kenya on the part of service providers, but also consumers. The most common challenges include inequity in the quality of service based on the ability to pay, service cut-offs, weak regulatory oversight and lack of accountability to local consumer needs. This paper shows that there is, however, consensus among water and sanitation service providers that privatization is likely to improve efficiency in water and sanitation services only if a collaborative effort is embraced in tackling public sector reform in Kenya. The paper also provides recommendations towards achieving privatization of water and sanitation services.
\end{abstract}

\section{Résumé}

Les services du secteur public dans les pays en voie de développement n'ont souvent pas été efficaces dans la fourniture de services fiables en matière d'eau et d'assainissement. À l'échelle mondiale, plus d'un milliard de personnes n'ont pas accès à des sources d'eau améliorées et 2,6 milliards d'individus n'ont pas accès à l'assainissement dans le monde entier. Chaque pays à travers le monde fait de plus en plus appel au secteur privé pour un appui à l’offre de services nécessaire

* Department of Gender and Development Studies, Egerton University, Kenya. E-mail kenyangena@yahoo.com 
en eau. À cette fin, la privatisation des services d'eau et d'assainissement est considérée comme un moyen rentable de fourniture de services qui améliore aussi la qualité et la performance. Cet article vise à mettre en exergue les connaissances, les attitudes et les pratiques générales en matière de privatisation pour les fournisseurs de services du secteur de l'eau et de l'assainissement, mais aussi les défis actuels dans la gestion de la privatisation des services d'eau et d'assainissement au Kenya et les difficultés confrontées par les consommateurs. Les défis les plus courants sont, entre autres, l’inégalité dans la qualité du service basée sur la capacité paiement, les interruptions de services, la faiblesse du régime réglementaire de surveillance, et l'absence de responsabilisation par rapport aux besoins des consommateurs locaux. Toutefois, les fournisseurs de services d'eau et d'assainissement conviennent que la privatisation ne peut améliorer l'efficacité des services d'eau et d'assainissement que si un effort de collaboration est adopté dans la gestion de la réforme du secteur public au Kenya. L'étude donne aussi des recommandations en vue de la réalisation de la privatisation des services d'eau et d'assainissement.

\section{Background Information}

In Kenya, privatization first became a major policy tool in the 1980s. The privatization endeavour began with the IMF/World Bank imposition of structural adjustment programs (SAPS) in the 1980s, which forced governments to free markets and pull of out of loss-making state enterprises whose lifeline was government subventions.

Scholars and development experts have defined privatization as a generic term used to describe a range of policy initiatives meant to alter ownership or management away from the government in favour of the private sector. Often, privatization has been confused with liberalization. In the latter, the government can retain ownership of public enterprises but commercialize them in pursuit of efficiency through improved management and pricingbased criteria.

This appears to be Kenya's chosen path in the provision of water services. After independence in 1963, the government formed the Ministry of Water Development to develop and oversee the country's water resources. The government embarked on improving access to safe and clean water with emphasis on a policy of implementing water projects on a self-help basis in which local communities took control. By the 1990s, however, it had become clear that this strategy was inadequate and the government lacked sufficient resources to match communities’ water needs (ROK 2002).

It was against this background that the need arose to revise the national water policy. This culminated in the National Policy on Water Resources Management and Development, Sessional Paper No. 1 of 1999, which was first drafted in 1992. Other policy blueprints included the Water Act 2002, 
the Country Strategy on Water and Sanitation Services and Country Strategy on Integrated Water Resources Management. The Water Act 2000 broadly sets out the legal implementation framework for implementing the privatization policy. The Act recognizes the role of independent water service providers and identifies the Water Services Regulatory Board (WSRB) as the statutory organ established to regulate their functions, principally through developing guidelines on applicable tariffs for the provision of water services (ROK 2002).

At the level of local authorities, the paradigm shift appears to be more towards commercialization under which it is presumed that efficiency in service delivery can be attained. Towards this end, most local authorities have formed or are in the process of forming municipal companies run on strict commercial lines under 'agency contracts' from the parent local authority. The emphasis by local authorities is towards ensuring that under the framework of commercialization, companies formed to provide water plough back the bulk of their earnings into improving service delivery while allowing local authorities to retain part of the earnings to cover costs such as personnel expenses. The experiences of local authorities that have embarked on commercialization, such as Nyeri, Eldoret and Kisumu, are often cited as examples of how efficiency can be infused without ceding control to private enterprises. For sanitation services, private companies seek licences from local authorities to collect and dispose of waste on behalf of municipalities.

\section{Literature Review}

Water is fundamental to all forms of life and must be protected as a common resource, public good and human right. Water has been recognized as a human right ${ }^{2}$ in numerous international treaties and declarations, as well as by the UN Committee on Economic, Social and Cultural Rights in November 2002. The human right to water is essential for achieving other human rights and international development commitments in critical areas such as sustainable development and poverty eradication. At the 2000 UN Millenium Summit, 191 heads of state recommended their governments adopt a global development agenda. The resulting eight Millennium Development Goals agenda (MDGS) provide numerical, time-bound targets to improve living conditions and remedy global imbalances by 2015. One specific target under goal 7 calls for halving the proportion of people without sustainable access to safe drinking water.

Many studies indicate that the majority of people worldwide are moving to towns/cities. According to Mwanza and Kariuki (2003), it is expected that over 50 per cent of the population in African countries will reside in urban areas by 2020 and that 20 to 50 per cent of urban residents will not have 
reliable access to water and sanitation services. Studies also estimate that at present about half the urban population in Sub-Saharan Africa does not have adequate access to water and an even higher percentage lacks adequate access to sanitation. The bottom-line argument is that water and sanitation systems that are properly designed, implemented and managed can offer services over a wide coverage area and at reasonable cost.

Further, several recent reports indicate that most developed countries emphasize privatization of public utilities and that this trend will continue to grow in the future. At the same time, studies carried out worldwide indicate that efficient management of water resources is critical for the survival of mankind.

\section{European Initiatives}

The European Water Legislation initiated in 1975, in a 'first wave', with standards for rivers and lakes used for drinking water abstraction, culminated in 1980 in the setting of binding quality targets for drinking water.

The Community Water Policy Ministerial Seminar in Frankfurt in 1988 reviewed existing legislation and identified gaps and proposed a number of improvements. On 10 November 1995, the European Union (EU) environmental agency presented an updated state of the Environment report Environment in the European Union - 1995, confirming the need for action to protect community waters in qualitative as well as quantitative terms. ${ }^{3}$ On 18 December 1995, the EU Council adopted conclusions requiring the drawing up of a new water framework directive establishing the basic principles of sustainable water policy in the EU.

The EU Council on 25 June 1996, the Committee of the Regions on 19 September 1996, the Economic and Social Committee on 26 September 1996 and the European Parliament on 23 October 1996, requested the Commission to come forward with a proposal for a water framework directive and to tackle urban wastewater problems in a coherent way. This is why the European Water Policy was developed in an open consultation process involving all parties who agreed on the need for a single legislatory framework to resolve these problems.

In due course the Commission presented a proposal for a water framework directive with the following key aims, among others (EU 2000):

- Expanding the scope of water protection to all waters, surface water and ground water

- Getting the citizen involved more closely

- Streamlining legislation. 
On 23 October 2000, the directive 2000/60/EC of the European Parliament and the Council establishing a Framework for Community Action in the Field of Water Policy, or in short the EU Water Framework Directive (EU WFD), was finally adopted. The directive was published in the official journal of the European Community (OJL 327) on 2 December 2000 and came into force the same day.

Subsequent international conferences related to freshwater management then focused on public-private participation as one of the most important issues. The Bonn recommendation in 2001, for example, stated strongly that decentralization was key because the local level was where national policy met community needs. Bonn's recommendation for action also called for making water attractive to private investment (ICFW 2001b)

The Bonn recommendation for action in particular focuses on publicprivate partnerships, noting that privately managed service delivery does not imply private ownership of water resources. It also recommends the use of the self-help potential of local communities to reduce the financial requirement of rural and urban projects for poverty alleviation by supporting nongovernmental organizations (NGOs) and others to develop micro finance capabilities. In the Second World Water Forum, public-private partnership was widely propagated.

The Bonn recommendation for action equally emphasized the need for special attention in the participation of all stakeholders, particularly the poor, who are often excluded from decision-making. The Ministerial Declaration of the Second World Water Forum urged wise government of water, so that the public and all stakeholders are included in the services but also participate actively in water resource management. The Bonn recommendation for action finally urged that decision-making, implementation of projects and operation of services be decentralized and that private service providers be responsible for management and operation of water service (ICFW 2001b).

\section{Kenya's Water Policy Framework}

Kenya is not regarded as a water-rich country. This reality underscores the government's move towards privatization of the water and sanitation sector. Even though the government indicates that privatization does not constitute a policy component for the sector, it is a discernible feature in its thinking about the water sector. According to Mutiso (1989), four-fifths of the country is arid and semi-arid and prone to drought. This justifies the need for the sustainable management of the country's limited water resources. The Water Act of 2002 is intended to provide for the conservation, control and apportionment of and use of its water resources. 


\section{The Water Act 2002}

This Act, which, has been in application since 17 October 2002 when it received presidential assent, sets out the key elements of Kenya's legislation on the water sector. Its preamble states that it is an Act of Parliament that sets out:

To provide for the management, conservation, use and control of water resources and for the acquisition and regulation of rights to use water; to provide for the regulation and management of water supply and sewerage services; to repeal the Water Act (cap. 237) and certain provisions of the Local Government Act; and for related purposes. (ROK 2002)

The Act seeks to address the shortcomings that resulted in wastage, manipulation and abuse of water sources and sanitation services. It creates the Water Resources Management Authority (WRMA) to oversee the use of water resources, which are all vested in the state.

According to the Act, WRMA is a body corporate which his charged with, among other duties:

- Developing principles, guidelines and procedures for the allocation of water resources

- Receiving and determining applications for permits for water use

- Regulating and protecting water resources quality from adverse impacts

- Determining charges to be imposed for the use of water from any water resource in accordance with guidelines in the National Water Resources Management Strategy

- Gathering and maintaining information on water resources and publishing forecasts, projections and information on water resources

- Liaising with other bodies for the better regulation and management of water resources

- Advising the Minister concerning any matter in connection with resources.

\section{Inclusiveness of the Water Act}

The Act emphasizes the role and participation of local communities. For instance, the minister responsible for water is required to formulate and publish in the Kenya Gazette a national water management strategy based on the outcome of public consultations. The policy of inclusiveness and grassroots participation in water conservation is further highlighted by the fact that the Act provides for the existence of a Catchments Area Advisory Committee of not more than 15 members in respect of each catchment area. Such committees, which have been constituted since the Act became opera- 
tional, are expected to oversee the use, development, conversation, protection and control of water resources within each catchment area (Wambua 2004).

\section{Regulation Under the Water Act}

The Water Act establishes the Water Services Regulatory Board (WSRB) whose core responsibilities include licensing providers of water services and determining standards for the provision of water services to consumers (Wambua 2004). Other statutory duties of the WSRB include:

- Monitoring compliance with established standards for the design, construction, operation and maintenance of facilities for water services

- Monitoring and regulating licences and to enforce licence conditions

- Advising licensees on procedures for dealing with complaints from consumers

- Developing guidelines for the fixing of tariffs for the provision of water services

- Developing model performance agreements for use between water service boards and water service providers

- Monitoring the operation of agreements between water service boards and water service providers, taking appropriate action to improve effectiveness.

In addition, the WSRB has statutory obligation for: dissemination of information about water services; promoting conservation and demand management measures in accordance with the National water services strategy. Other functions of the regulatory board are determining fees, taxes, premiums and charges to be imposed for water services.

\section{Statement of the Problem}

The essence of water privatization policy is to ensure a better and more efficient management of water and sanitation services. However, the implementation process challenges relate to proper design and management principles. These challenges have led the central government and the local authorities to invest substantially in improving the infrastructure to satisfy the water needs of the consumers. Secondly, the knowledge, attitudes and practices of service providers in the water sector seem to be clinging to the premise that they know what development beneficiaries want as opposed to involving them in planning and implementation of projects. Lastly, there are governance issues in the management of the water and sanitation sector, and especially in defining a sound regulatory mechanism, which does not compromise service delivery, ecology and national sovereignty. 


\section{Justification of Privatization of Water and Sanitation Services}

Privatization of water and sanitation services is likely to produce important benefits beyond cost savings and improved performance if the water policy is well designed and managed by all stakeholders. Equally, the central government and local authorities can deliver economically viable services given a clear institutional and operational framework. This can be achieved if the attitudes, knowledge and practices of water service providers towards consumers change to incorporate them into decision-making. This paper therefore calls for the articulation of a framework of efficient water management in Kenya.

Objectives of the study

1. To examine the experiences in privatization of water and sanitation services in Kenya.

2. To establish knowledge, attitudes and practices (KAP) of the service providers in relation to management of water resources and sanitation services.

3. To determine the constraints to effective management of water and sanitation services in Kenya.

\section{Methodology}

The design of the study comprised of two mutually reinforcing data collection methods with the aim of collecting mainly qualitative data. Selected literature on privatization of water and sanitation services was reviewed to derive generalized experiences of water privatization. The study also used purposive sampling to interview four key service providers, namely, the district water engineer, municipal water engineer and two officers working with Nakuru Water Services Company, all based in Nakuru district. A structured questionnaire with both open-ended and closed questions was used to interview the officers. The purpose of the interviews was to determine the challenges faced in the privatization of water and sanitation services and also establish the knowledge, attitudes and practices of the service providers on privatization.

\section{Challenges in Privatization of Water and Sanitation Services in Kenya}

The privatization of water is a radical new social experiment. Most major water privatizations are less than a decade old, but already it appears clear that they follow the pattern of privatization in other service sectors. Some of the challenges include: lack of commitment to expanded access to low-income consumers; inequity in the quality of service based on the ability to 
pay; service cut-offs' weak regulatory oversight' and lack of accountability to local consumer needs.

For a long time, the absence of a law on privatization establishing legal parameters and a framework on water rights was a major area of weakness and concern, often creating uncertainty and a policy vacuum. This partly explains the problems encountered in water privatization. In spite of the steps it has taken, it must be recognized that Kenya is yet to develop an effective policy on water privatization and management of water resources. All the service providers interviewed felt that some service providers and a majority of water consumers were not aware that there exists a Water Act meant to give guidelines on privatization of water and sanitation services. In particular, the role and relationship among various government departments is still not well defined, often resulting in conflict and competition over control and autonomy. As already noted, the absence of a well-constructed statute on privatization has left the legislative framework spread across a multiplicity of often competing and contradictory statutes.

While applauding the government's determination to supply adequate water in both urban and rural areas, privatization efforts have been hampered by lack of resources, administrative incompetence, bad governance and dwindling funds against an ever-increasing demand for water to meet consumption, industrial and agricultural needs (Nation, December 2004; PANA/UN Habitat, November 2004). The district water engineer in particular singled out lack of adequate funds and staff incompetence in implementing privatization of water and sanitation services. As regards bad governance, he stated that political interference by both councillors and members of Parliament in the appointment of the staff working in water companies and committees had adversely affected the competencies in implementing such crucial reforms. Study results also observed that politicians seek to appoint their close political associates irrespective of their education, status and competence to serve in the crucial water committees. Such officers are bound to pledge their loyalty more to their sponsoring politicians than their employers.

Secondly, some of the water committees are comprised of civil servants such as Provincial Commissioners (PC), District Commissioners (DC), District Officers (DO), Chiefs and assistant chiefs. The inclusion of such officers raises questions related to accountability, transparency and the competencies of the committee members, especially service providers who are either ignorant of or unlikely to be familiar with policy guidelines.

In past years, the central government showed little enthusiasm in forging close links with civil society organizations to improve water provision. On this note, HABITAT underscores the importance of inclusive practices on 
good governance in prioritizing the delivery of services to the poor. For example, efforts to fence off the Entarara Springs in Loitokitok, Kajiado, whose water emanates from Mt Kilimanjaro, were frustrated. The Netherlands Development Organization invested millions of Kenya shillings to protect the springs but the Provincial Administration was reluctant to assign personnel to guard this ecologically sensitive area. On the contrary, fencing material was routinely stolen, thus frustrating the project (RTI International).

A number of studies identify stakeholder participation as one of the most important issues in the management of water. Water can empower people, and particularly the process of water management. The Dublin Principle 2, for example, calls for development and management of water through a participatory approach, involving users, planners and policy-makers at all levels. IWRM requires decisions at the lowest appropriate level, with full consultation and involvement of the users in the planning and implementation of projects. In view of such neglect over the years, it is now estimated that Kenya needs to invest Kshs 300 billion (US\$4 billion) to ensure access to clean and safe water by all Kenyans. This is almost the equivalent of the country's total annual national budget. Nairobi alone requires a staggering $\$ 150$ million (Ksh. 11 billion).

Over and above the limited government spending, inefficiency and corruption have been further blamed for the current situation. Even in cases where commercialization has taken off on a sound basis, there are still governance issues that remain to be addressed. For instance, the Nyeri Water and Sewerage Company, a private company fully owned by the Nyeri Municipal Council to manage water supplies in the town, continues to lose an estimated 40 per cent of its water through leakages and diversion. According to a joint report prepared by the World Bank and Ministry of Water, 'only about 42 per cent of households have actual connections serviced by Nairobi City Council Water and Sewerage Department. Unaccounted water is in excess of 50 per cent.' In Nakuru, the water officers working with the Nakuru Water and Sanitation Company (NWC) allege that illegal water connections by unscrupulous people has led to the loss of millions of shillings by the company because the water is unaccounted for.

Whereas the government has a social contract with its citizens, certain autonomous companies formed under the Water Act 2002 are pursuing profit as opposed to social goals. This has caused concern that the Water Act does not adequately safeguard the interests of the poor (mostly women), especially from price increases. ${ }^{4}$ In cases where residents trek long distances to access water or sanitation places women especially are in danger of becoming victims of physical violence. 
In some cities, water and sanitation services are mainly provided by independent vendors/providers who operate without any regulatory mechanisms and charge inflated prices for substandard services. ${ }^{5}$ Hygiene is also compromised during periods of water shortage. These water-related challenges are intrinsically linked to sanitation services. Most slum households, for example, do not have toilet facilities; thus, residents are obliged to go to commercial toilets or to adopt unorthodox toileting means and strategies, such as using plastic bags that are disposed of haphazardly.

It has also been argued that the decision-making power of local governments in most African countries is limited in face of a highly centralized political, tax-revenue-raising and administrative authority. Despite indications of support for decentralization, local governments and cities in general are inhibited in making major investment decisions, adopting long-term plans, signing concession contracts or introducing structural and institutional reform without the approval of the central government authority (Brockemhurst and Janssen 2004).

Further, in most cases, the local authorities often do not have the expertise to negotiate with private companies on issues such as design, bidding processes or concession contracts. Additionally, the professionals working with the government water department charged with the responsibility of providing water services are rarely given the managerial and financial autonomy they need to carry out their functions properly. The centralized system of managing water utilities, particularly those under the Ministry of Water Resources Management and Development (MWRMD) and the National Water Conservation and Pipeline Corporation, makes efficient operations difficult.

\section{Prospects}

Current trends in Kenyan society indicate that water-related development prospects are threatened. Significant shortcomings in the prevailing management of water and sanitation services must therefore be remedied. The expectation is that change will lead to a better life with more opportunities and improvements in quality of life.

Subsequently, since the articulation of the policy framework on economic reforms (1996-8), the National Development Policy (1997-2001) and the National Water Policy (1998), the Kenya government's emphasis has favoured increased community and private sector participation. Since 2003, there has been increased emphasis on evolving an enabling institutional framework that vests greater autonomy on local authorities in the management of water resources.

Understandably, the focus in local authorities involved in privatization has been on emphasizing commercialization based on an application of business 
principles of sustainability in managing water resources. Most local authorities are convinced that commercialization would ensure efficient provision of water at affordable prices, supporting water demand management at the level of the local authority to secure maximum benefits for local communities.

The Gurria Taskforce, reporting in 2006, for example, stressed the importance of the municipal level and the need to give more focus to demand. Over the past few years, financing water for all has clearly become a key global issue for many and varied agencies, including the World Bank, Global Water Partnership, World Water Council and European Union Water Initiative, among others. Awareness on this issue in Kenya has been raised significantly, although it takes time to convert ideas into action.

In conclusion, the process of privatization of water resources in some cities is being taken seriously. To achieve this there is need for utmost vigilance for all stakeholders, including resource managers, policy-makers, scientists, and consumers. Agreement is needed on the kind of governance system that is required to respond to the challenges associated with the objectives of water-related development. Every stakeholder can and should play a constructive role in striving towards sustainability in a changing world. The Draft Bill on privatization also explains the government's determination to legislate on management of the privatization framework

\section{Recommendations}

The study makes the following recommendations:

- The Bonn recommendation for action states that participation of all stakeholders who use or protect water resources and their ecosystem is required, and special attention is needed to improve the participation of those people, particularly the poor, who are often excluded from decision-making. The Ministerial Declaration of the Second World Water Forum urges the wise government of water, to secure the involvement of public and accommodate the interests of all stakeholders in the services but also their active participation in water resource management. In order to achieve efficient, equitable and sustainable water management within the IWRM approach, the principle of the subsidiary, which drives down action to the lowest appropriate level, will need to be observed.

- There is need to strike a balance between achieving market efficiency vis-à-vis promoting social equity on access to this vital resource, especially by the most vulnerable sections of the population.

- The Kenya government needs to develop and mobilize human resources to meet new challenges and also to seize opportunities for 
advancements in knowledge, more effective technologies etc. Capacity for poor communities must be entrenched in order to instigate a combination of self-confidence and capacity-building to overcome poor water and sanitation services.

- Equally, the government needs to develop a better storage system of water, especially dams. The National Water Services strategy indicates that the sector has low-wage skilled personnel that need retraining to work with the evolving technology of water delivery systems.

- Inevitably, the involvement of various stakeholders including donors, civil society and local communities is critical in defining the way forward on Kenya's water sector, paying due regard to the interests of the poor. Moreover, there is an urgent need for regulatory mechanisms to protect slum residents from exploitation (e.g. the pricing and quality of water, requirements for landlords to provide proper toilets).

- There is no doubt that Kenyans require a strong and sustained political will to implement challenges in the framework within which water utilities function. Equally important is the need to inform the public and build popular support for water sector reforms. The focus must then be on providing strong incentives for utilities to improve performance and especially for reaching unserved poor people.

\section{Notes}

1. Throughout the developing countries there is evident demand for water, sanitation and hygiene services.

2. Water is a limited natural resource and a public good fundamental for life and health. The human right to water is indispensable for leading a life in human dignity. It is a prerequisite for the realization of other human rights.

3. The Dublin Principles, generated at the 1992 Dublin conference on water and the environment, recognize that fresh water is a finite and valuable resource, essential to sustain life, development and the environment. But they also declare that water has an economic value in all its competing uses, and should therefore be recognized as an economic good.

4. Private property regimes tend to perpetuate and can even intensify gender inequalities. Women are always marginalized in the monetary economy, and thus suffer when a price is put on water. Willingness to pay is not the same as the ability to pay; such assessments do not take into account the choices that poor women must make. Women have been the most adversely affected by these increases [in water prices] because in most cases power at the household level is concentrated in the hands of men. Men care little about water bills and how and where the water is obtained. 
5. For those with running water, cut-offs occur regularly and local councils and officers in water companies attribute this to non-payment of bills by some consumers. However, there was agreement among interviewees that some water companies charge higher user fees that mean people are unable to pay.

\section{References}

Brocklehurst, C. and Janssens, Jan G., 2004, Innovative Contracts, Sound Relationships: Urban Water Sector Reform in Senegal, Water Supply and Sanitation Sector Board, Discussion Paper No. 1, Washington, D.C.: World Bank, January.

EU, 2000, Directive 2000/60/EU of the European Parliament and of the Council of 23 October 2000 Establishing a Framework of Community Action in the Field of Water Policy, Official Journal of the European Community (L 327): 1-72.

GWP, 2002a, IWRM-At a Glance:, Stockholm: Global Water Partnership Secretariat, Technical Advisory Committee.

GWP, (2002b, IWRM Toolbox: A Tool Box to Support IWRM, Stockholm: Global Water Partnership, available online: www.gwpforum.org

ICFW, 2001a, Conference Outcomes, The Bonn Keys International Conference on Fresh Water, Bonn, 3-7 December, available online: www.water-2001.de

ICFW, 2001b, Conference Outcomes: Bonn Recommendations for Action, The Bonn Keys International Conference on Fresh Water, Bonn 3-7 December, available online: www.water-2001.de

Kessler, T., 2003, From Social Contract to Private Contract: The Privatization of Health, Education and Basic Infrastructure, Social Watch Report, available online: www.socwatch.org/uy

Liu, J., n.d, Human Rights and Gender Inequality in Water Resource Management, New York: Centre for Economic and Social Rights, available online: www.cesr.org

Mutiso, G. C., 1989, Managing Kenya’s Arid and Semi-arid Areas, in Kirino, A. and Juma, C. (eds), Gaining Ground: Institutional Innovations in Land Use in Kenya, Nairobi: African Centre for Technology Studies.

Mwanzia, D. and Kariuki, M., 2003, Better Water and Sanitation for the Urban Poor: Good practice from Sub-Saharan Africa, European Communities and Water Utility Partnership, PANA/UN-HABITAT, 8, November 2004.

Obando, Ana Elena, 2003, Women and Water Privatization, November, Women's Human Rights net, www.whrnet.org/docs/issue-water.html

Republic of Kenya (ROK), 1999, National Poverty Eradication Plan, 1999-2015, Nairobi: Government Printer.

Republic of Kenya (ROK), 2002, National Development Plan 2002-2008, Nairobi: Government Printer.

RTI International, 3040 Cornwallis Road, Research Triangle Park, NC 27709-2194. 
United Nations Committee on Economic, Social and Cultural Rights, 2002, International Covenant on Economic, Social and Cultural Rights (ICECR) E/ C12/2002/1 [General Commitment No. 15, The Right to Water, 26 November, available online, www.unhchr.ch/tbs/doc.nsf]

Wambua, S., 2004, Water Privatisation in Kenya, Global Issue Papers No. 8, Berlin: Heinrich Böll Foundation. 